\title{
Highlight report: overview of hepatoprotective compounds
}

\author{
Agata Widera $^{1}$
}

Published online: 27 November 2015

(C) Springer-Verlag Berlin Heidelberg 2015

Recently, Robert Domitrović and Iva Potočnjak from Rijeka University in Croatia have published a comprehensive review article about the mechanisms of action and clinical perspectives of hepatoprotective natural compounds (Domitrović and Potočnjak 2015). Key evidence of the 27 most promising and most intensively studied phytochemicals has been summarized and critically discussed. Since the mode of action of most hepatotoxic compounds often includes generation of oxidative stress (Godoy et al. 2013; Tolosa et al. 2013; Lu and Cederbaum 2010; Reif 2010; Chang and Abbott 2006), it is not surprising that antioxidant properties often play a key role. However, recently, antifibrotic effects have been shown to be due to immune cell-stellate cell interactions (Puche et al. 2013; Gressner and Weiskirchen 2006; Baeck and Tacke 2014). Particularly, natural killer cells have been shown to induce killing of activated stellate cells (Tian et al. 2013; Zimmermann and Tacke 2011). Therefore, it is plausible that hepatoprotective phytochemicals act by inducing apoptosis of stellate cells or stimulation of matrix degradation (Domitrovic and Potocnjak 2015). Further mechanisms include binding to pro- or antiapoptotic proteins, inhibition of tyrosine protein kinases, interaction with signal transduction pathways, such as PI3 K, IKK and COX-2, as well as modification of the DNA-binding activity of transcriptional regulators (Peck et al. 2006; Domitrović and Potočnjak 2015).

Currently, mechanisms of hepatotoxicity represent a cutting-edge topic in toxicological research (Hwang et al.

Agata Widera

widera@ifado.de

1 IfADo - Leibniz Research Centre for Working Environment and Human Factors, Ardeystr. 67, 44139 Dortmund, Germany
2014; Hammad 2014; Campos et al. 2014; Vitins et al. 2014; Liu et al. 2014; Dias da Silva et al. 2013; Schyschka et al. 2013; Rodrigues et al. 2013; Driessen et al. 2013). Moreover, liver in vitro systems (Chen et al. 2014; Vinken et al. 2014; Godoy et al. 2013; 2015; Ghallab 2014; Reif 2014; Godoy 2011; Ilkavets 2013; Messner et al. 2013) have been intensively applied and systems biology approaches (Schliess et al. 2014; Drasdo et al. 2014a, b; Hoehme et al. 2010) have been introduced to gain a deeper understanding of the mechanisms of hepatotoxicity. Considering this background, the present review of Domitrović and Potočnjak is a must read for anyone interested in how protective compounds can interfere with hepatotoxic mechanisms.

\section{References}

Baeck C, Tacke F (2014) Balance of inflammatory pathways and interplay of immune cells in the liver during homeostasis and injury. EXCLI J 13:67-81 (eCollection 2014)

Campos G, Schmidt-Heck W, Ghallab A, Rochlitz K, Pütter L, Medinas DB, Hetz C, Widera A, Cadenas C, Begher-Tibbe B, Reif R, Günther G, Sachinidis A, Hengstler JG, Godoy P (2014) The transcription factor CHOP, a central component of the transcriptional regulatory network induced upon $\mathrm{CCl} 4$ intoxication in mouse liver, is not a critical mediator of hepatotoxicity. Arch Toxicol 88(6):1267-1280. doi:10.1007/s00204-014-1240-8

Chang TK, Abbott FS (2006) Oxidative stress as a mechanism of valproic acid-associated hepatotoxicity. Drug Metab Rev 38(4):627-639 (Review)

Chen M, Tung CW, Shi Q, Guo L, Shi L, Fang H, Borlak J, Tong W (2014) A strategy to predict risk for drug-induced liver injury in humans using high-content screen assays and the 'ruleof-two' model. Arch Toxicol 88(7):1439-1449. doi:10.1007/ s00204-014-1276-9

Dias da Silva D, Carmo H, Lynch A, Silva E (2013) An insight into the hepatocellular death induced by amphetamines, individually and in combination: the involvement of necrosis and apoptosis. Arch Toxicol 87(12):2165-2185. doi:10.1007/s00204-013-1082-9 
Domitrović R, Potočnjak I (2015) A comprehensive overview of hepatoprotective natural compounds: mechanism of action and clinical perspectives. Arch Toxicol. doi:10.1007/ s00204-015-1580-z

Drasdo D, Hoehme S, Hengstler JG (2014a) How predictive quantitative modelling of tissue organisation can inform liver disease pathogenesis. J Hepatol 61(4):951-956. doi:10.1016/j. jhep.2014.06.013

Drasdo D, Bode J, Dahmen U, Dirsch O, Dooley S, Gebhardt R, Ghallab A, Godoy P, Häussinger D, Hammad S, Hoehme S, Holzhütter HG, Klingmüller U, Kuepfer L, Timmer J, Zerial M, Hengstler JG (2014b) The virtual liver: state of the art and future perspectives. Arch Toxicol 88(12):2071-2075. doi:10.1007/ s00204-014-1384-6

Driessen M, Kienhuis AS, Pennings JL, Pronk TE, van de Brandhof EJ, Roodbergen M, Spaink HP, van de Water B, van der Ven LT (2013) Exploring the zebrafish embryo as an alternative model for the evaluation of liver toxicity by histopathology and expression profiling. Arch Toxicol 87(5):807-823. doi:10.1007/ s00204-013-1039-z

Ghallab A (2014) The rediscovery of HepG2 cells for prediction of drug induced liver injury (DILI). EXCLI J 13:1286-1288

Godoy P (2011) Hepatotoxicity. EXCLI J 10:124-127

Godoy P, Hewitt NJ, Albrecht U, Andersen ME, Ansari N, Bhattacharya S, Bode JG, Bolleyn J, Borner C, Böttger J, Braeuning A, Budinsky RA, Burkhardt B, Cameron NR, Camussi G, Cho CS, Choi YJ, Craig Rowlands J, Dahmen U, Damm G, Dirsch O, Donato MT, Dong J, Dooley S, Drasdo D, Eakins R, Ferreira KS, Fonsato V, Fraczek J, Gebhardt R, Gibson A, Glanemann M, Goldring CE, Gómez-Lechón MJ, Groothuis GM, Gustavsson L, Guyot C, Hallifax D, Hammad S, Hayward A, Häussinger D, Hellerbrand C, Hewitt P, Hoehme S, Holzhütter HG, Houston JB, Hrach J, Ito K, Jaeschke H, Keitel V, Kelm JM, Kevin Park B, Kordes C, Kullak-Ublick GA, LeCluyse EL, Lu P, Luebke-Wheeler J, Lutz A, Maltman DJ, Matz-Soja M, McMullen P, Merfort I, Messner S, Meyer C, Mwinyi J, Naisbitt DJ, Nussler AK, Olinga P, Pampaloni F, Pi J, Pluta L, Przyborski SA, Ramachandran A, Rogiers V, Rowe C, Schelcher C, Schmich K, Schwarz M, Singh B, Stelzer EH, Stieger B, Stöber $\mathrm{R}$, Sugiyama Y, Tetta C, Thasler WE, Vanhaecke T, Vinken M, Weiss TS, Widera A, Woods CG, Xu JJ, Yarborough KM, Hengstler JG (2013) Recent advances in 2D and 3D in vitro systems using primary hepatocytes, alternative hepatocyte sources and non-parenchymal liver cells and their use in investigating mechanisms of hepatotoxicity, cell signaling and ADME. Arch Toxicol 87(8):1315-1530. doi:10.1007/s00204-013-1078-5 (Review)

Godoy P, Schmidt-Heck W, Natarajan K, Lucendo-Villarin B, Szkolnicka D, Asplund A, Björquist P, Widera A, Stöber R, Campos G, Hammad S, Sachinidis A, Chaudhari U, Damm G, Weiss TS, Nüssler A, Synnergren J, Edlund K, Küppers-Munther B, Hay DC, Hengstler JG (2015) Gene networks and transcription factor motifs defining the differentiation of stem cells into hepatocyte-like cells. J Hepatol 63(4):934-942. doi:10.1016/j.jhep.2015.05.013

Gressner AM, Weiskirchen R (2006) Modern pathogenetic concepts of liver fibrosis suggest stellate cells and TGF-beta as major players and therapeutic targets. J Cell Mol Med 10(1):76-99 (Review)

Hammad S (2014) The CHOP conundrum: controversial discussion about the role of endoplasmic reticulum stress in hepatotoxicity. Arch Toxicol 88(8):1477-1478. doi:10.1007/s00204-014-1304-9

Hoehme S, Brulport M, Bauer A, Bedawy E, Schormann W, Hermes M, Puppe V, Gebhardt R, Zellmer S, Schwarz M, Bockamp E, Timmel T, Hengstler JG, Drasdo D (2010) Prediction and validation of cell alignment along microvessels as order principle to restore tissue architecture in liver regeneration. Proc Natl Acad Sci USA 107(23):10371-10376. doi:10.1073/pnas.0909374107
Hwang JH, Kim YH, Noh JR, Gang GT, Kim KS, Chung HK, Tadi S, Yim YH, Shong M, Lee CH (2014) The protective role of $\mathrm{NAD}(\mathrm{P}) \mathrm{H}$ :quinone oxidoreductase 1 on acetaminophen-induced liver injury is associated with prevention of adenosine triphosphate depletion and improvement of mitochondrial dysfunction. Arch Toxicol. doi:10.1007/s00204-014-1340-5

Ilkavets I (2013) A special issue about hepatotoxicity and hepatocyte in vitro systems. Arch Toxicol 87(8):1313-1314. doi:10.1007/ s00204-013-1092-7

Liu A, Krausz KW, Fang ZZ, Brocker C, Qu A, Gonzalez FJ (2014) Gemfibrozil disrupts lysophosphatidylcholine and bile acid homeostasis via PPAR $\alpha$ and its relevance to hepatotoxicity. Arch Toxicol 88(4):983-996. doi:10.1007/s00204-013-1188-0

Lu Y, Cederbaum AI (2010) CYP2E1 potentiation of LPS and TNF $\alpha$ induced hepatotoxicity by mechanisms involving enhanced oxidative and nitrosative stress, activation of MAP kinases, and mitochondrial dysfunction. Genes Nutr 5(2):149-167. doi:10.1007/s12263-009-0150-5

Messner S, Agarkova I, Moritz W, Kelm JM (2013) Multi-cell type human liver microtissues for hepatotoxicity testing. Arch Toxicol 87(1):209-213. doi:10.1007/s00204-012-0968-2

Peck MC, Fisher RF, Long SR (2006) Diverse flavonoids stimulate NodD1 binding to nod gene promoters in Sinorhizobium meliloti. J Bacteriol 188:5417-5427

Puche JE, Saiman Y, Friedman SL (2013) Hepatic stellate cells and liver fibrosis. Compr Physiol 3(4):1473-1492. doi:10.1002/cphy. c120035 (Review)

Reif R (2010) Oxidative stress. EXCLI J 2010(9):154-155

Reif R (2014) The body-on-a-chip concept: possibilities and limitations. EXCLI J 13:1283-1285

Rodrigues AV, Rollison HE, Martin S, Sarda S, Schulz-Utermoehl T, Stahl S, Gustafsson F, Eakins J, Kenna JG, Wilson ID (2013) In vitro exploration of potential mechanisms of toxicity of the human hepatotoxic drug fenclozic acid. Arch Toxicol 87(8):1569-1579. doi:10.1007/s00204-013-1056-y

Schliess F, Hoehme S, Henkel SG, Ghallab A, Driesch D, Böttger J, Guthke R, Pfaff M, Hengstler JG, Gebhardt R, Häussinger D, Drasdo D, Zellmer S (2014) Integrated metabolic spatial-temporal model for the prediction of ammonia detoxification during liver damage and regeneration. Hepatology 60(6):2040-2051. doi:10.1002/hep.27136

Schyschka L, Sánchez JJ, Wang Z, Burkhardt B, Müller-Vieira U, Zeilinger K, Bachmann A, Nadalin S, Damm G, Nussler AK (2013) Hepatic 3D cultures but not 2D cultures preserve specific transporter activity for acetaminophen-induced hepatotoxicity. Arch Toxicol 87(8):1581-1593. doi:10.1007/s00204-013-1080-y

Tian Z, Chen Y, Gao B (2013) Natural killer cells in liver disease. Hepatology 57(4):1654-1662. doi:10.1002/hep.26115 (Review)

Tolosa L, Gómez-Lechón MJ, Pérez-Cataldo G, Castell JV, Donato MT (2013) HepG2 cells simultaneously expressing five P450 enzymes for the screening of hepatotoxicity: identification of bioactivable drugs and the potential mechanism of toxicity involved. Arch Toxicol 87(6):1115-1127. doi:10.1007/s00204-013-1012-x

Vinken M, Maes M, Oliveira AG, Cogliati B, Marques PE, Menezes GB, Dagli ML, Vanhaecke T, Rogiers V (2014) Primary hepatocytes and their cultures in liver apoptosis research. Arch Toxicol 88(2):199-212. doi:10.1007/s00204-013-1123-4 (Review)

Vitins AP, Kienhuis AS, Speksnijder EN, Roodbergen M, Luijten M, van der Ven LT (2014) Mechanisms of amiodarone and valproic acid induced liver steatosis in mouse in vivo act as a template for other hepatotoxicity models. Arch Toxicol 88(8):1573-1588. doi:10.1007/s00204-014-1211-0

Zimmermann HW, Tacke F (2011) Modification of chemokine pathways and immune cell infiltration as a novel therapeutic approach in liver inflammation and fibrosis. Inflamm Allergy Drug Target 10(6):509-536 